\title{
Sward structural characteristics and ingestive behaviour of beef heifers in a Pearl Millet pasture
}

\author{
Denise Baptaglin Montagner ${ }^{*}$, Marta Gomes da Rocha ${ }^{2}$, Teresa Cristina Moraes Genro ${ }^{3}$, \\ Fernando Luiz Ferreira de Quadros ${ }^{2}$, Juliano Roman ${ }^{1}$, Dalton Roso ${ }^{1}$
}

\footnotetext{
1 Programa Pós-Graduação em Zootecnia, Universidade Federal de Santa Maria, RS.

${ }^{2}$ Departamento de Zootecnia, Universidade Federal de Santa Maria, RS.

${ }^{3}$ EMBRAPA Pecuária Sul, Bagé, RS.
}

\begin{abstract}
Ingestive behaviour of beef heifers and sward structural characteristics of Pearl Millet (Pennisetum americanum (L.) Leeke) were evaluated. The experiment was carried out in a randomized complete design following a repeated measure arrangement (three experimental periods) with three replications of two leaf blade masses (600 and 1,000 kg/ha DM), which were maintained using continuous grazing with variable stocking rate. The variables measured were sward height, herbage mass, leaf blade and stem bulk density in sward vertical strata (sward structural characteristics), grazing, idling, rumination time and bite rate of heifers (ingestive behaviour). Bite rate was modified by pasture management and was lower when the leaf blade mass was $1,000 \mathrm{~kg} / \mathrm{ha} \mathrm{DM}$. The daily grazing, rumination and idling time of beef heifers were similar for both leaf blade masses. Structural variation of the sward, during the experimental period, altered the grazing, rumination and idling time of heifers, and affected the bite rate. In Southern Brazil, the beef heifers concentrate their grazing activities in the 12 p.m. to 6:00 p.m. period, decreasing the grazing between 12 a.m. and 6:00 a.m., even in the hottest season of the year.
\end{abstract}

Key Words: bite rate, grazing time, leaf blade bulk density, Pennisetum americanum, rumination time

\section{Características estruturais do pasto e comportamento ingestivo de novilhas de corte em pastagem de milheto}

\begin{abstract}
RESUMO - Foi avaliado o comportamento ingestivo de novilhas de corte e as características estruturais do milheto (Pennisetum americanum (L.) Leeke). Utilizou-se o delineamento inteiramente casualizado com medidas repetidas no tempo (três períodos), duas massas de lâmina foliar (600 e $1.000 \mathrm{~kg} / \mathrm{ha}$ de MS), mantidas por lotação contínua e com ajuste de carga, e três repetições. Avaliaram-se a altura do dossel, a massa de forragem, a densidade de lâminas foliares e colmos nos estratos verticais do pasto (características estruturais do dossel), os tempos de pastejo, ruminação e ócio e a taxa de bocados das novilhas (comportamento ingestivo). A taxa de bocados foi influenciada pelo manejo do pasto e foi menor quando a massa de lâmina foliar foi de $1.000 \mathrm{~kg} / \mathrm{ha}$ de MS. Os tempos diários de pastejo, ruminação e ócio de novilhas de corte foram semelhantes entre as massas de lâmina foliar. As variações estruturais do pasto ao longo do tempo de utilização promoveram modificações nos tempos de pastejo, ruminação e ócio das novilhas e afetaram a taxa de bocados. Na Região Sul do Brasil, as novilhas concentram suas atividades de pastejo no período das $12 \mathrm{~h}$ às $18 \mathrm{~h}$, diminuindo entre $24 \mathrm{~h}$ e $6 \mathrm{~h}$, mesmo na estação mais quente do ano.
\end{abstract}

Palavras-chave: densidade de lâminas foliares, Pennisetum americanum, taxa de bocado, tempo de pastejo, tempo de ruminação

\section{Introduction}

Sward structural changes may be relevant to determine variations in forage intake and on animal grazing performance. The degree of animal selective grazing is influenced by the sward structural characteristics and the grazing efficiency determines the quantity of nutrients ingested (Carvalho et al., 2007).
The structure of the sward is defined as the result of the growing dynamic of the plants components in space (Carvalho et al., 2001). Forage mass, sward height and bulk density are structural characteristics that directly influence bite mass (Reis \& Da Silva, 2006). When bite mass decreases, cattle are able to adjust their behaviour pattern in order to keep the level of intake compatible with their nutritional demands by increasing bite rate and grazing time in both

Received August 29, 2008 and accepted March 12, 2009.

Corresponding author:demontagner@yahoo.com.br

*Endereço atual: Embrapa Gado de Corte, Rodovia BR 262, Km 4, Caixa Postal 154, CEP: 79002-970, Campo Grande, MS. 
temperate (Jamieson \& Hodgson, 1979) and tropical pastures (Palhano et al., 2007).

A herbage mass is used in order to determine the pasture management, but the concept herbage mass does not have any relation with its components, such as the proportion of stems and leaves (Heringer \& Carvalho, 2002), which vary immensely throughout the pasture cycle. Green leaf blade mass, more than forage mass, is the adequate indicator for forage species management (Maraschin, 2000). This statement can have more influence on grasses that, under favorable environmental circumstances, present high herbage accumulation in a short period of time such as Pearl Millet (Pennisetum americanum (L.) Leeke). Leaf dispersion along the sward, since leaves are preferred by grazing animals, will determine the mass of each bite and how easily each bite will be taken (Hodgson, 1990). Knowledge of the interaction between plants and animals helps management decisions because the grazing behaviour is modified by sward structure, which is also altered by the grazing process (Carvalho et al., 2001), and it may result in changes in tiller density and persistency (Hodgson, 1990).

This experiment was carried out to evaluate the effects of sward structural characteristics on the ingestive behaviour of beef heifers on Pearl Millet pasture managed at two leaf blade masses (600 and 1,000 kg/ha of DM).

\section{Material and Methods}

This study was carried out at the Departamento de Zootecnia of the Universidade Federal de Santa Maria (UFSM), Rio Grande do Sul, Brazil, in the Central Depression geographical region of Rio Grande do Sul state, Brazil ( $29^{\circ} 43^{\prime} \mathrm{S}, 53^{\circ} 42^{\prime} \mathrm{W}$ and altitude of $95 \mathrm{~m}$ ). The experimental period lasted from $12 / 31 / 2001$ to $4 / 04 / 2002$, totaling 94 days of pasture use.

The region has a humid subtropical climate (Cfa) according to the Köppen classification. Rainfall, global radiation and minimum, average and maximum temperature data during the experimental period were recorded at the Estação Metereológica do Departamento de Fitotecnia da UFSM(Figure 1).

The experimental area was divided up into six paddocks totalizing 6.0 ha. A contiguous 1.8 ha area was used as a grazing paddock for additional heifers added to or removed from the paddocks as required. The soil in the experimental area is classified as a Paleaudalf soil (EMBRAPA, 1999) and Pearl Millet (Pennisetum americanum L. Leeke) was sowed on 11/28/2001 by no till with $35 \mathrm{~kg}$ seeds/ha. Paddocks received $250 \mathrm{~kg} / \mathrm{ha}$ fertilizer (5-20-20) and nitrogen (N) fertilization was $130 \mathrm{~kg} / \mathrm{ha}$, subdivided in three applications.

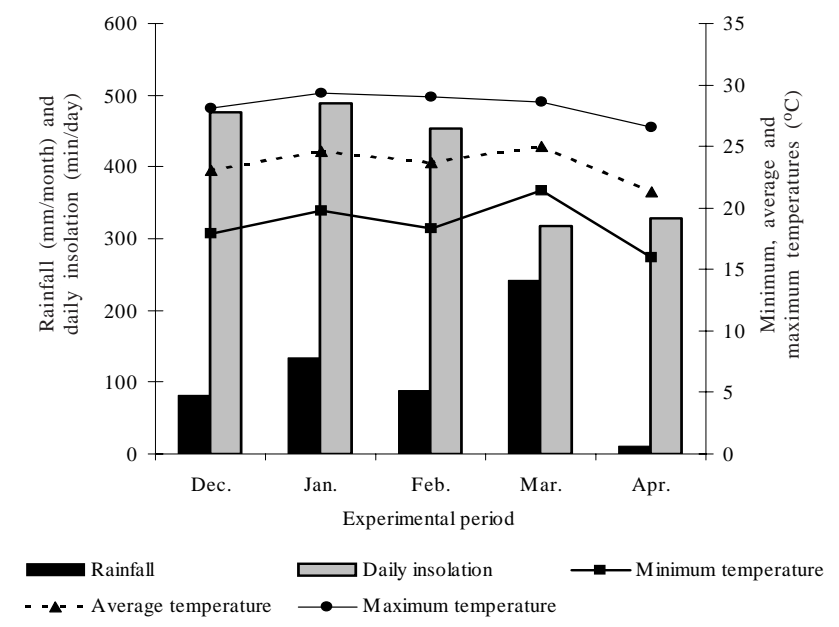

Figure 1 - Average monthly rainfall (mm), daily solar incidence (minutes), minimum, average and maximum temperature $\left({ }^{\circ} \mathrm{C}\right)$ during the experimental period from December 2001 to April 2002

Treatments corresponded to two leaf blade masses (LBM): 600 and 1,000 kg/ha estimated at 15 days interval with equations for each treatment and period based on the double sampling technique ('t Mannetje, 2000) at 20 measurement points. Samples for these calibrations were cut as close as possible to the soil surface. Samples collected were separated into leaf blade, stems + sheath and dead material components and dried at $65^{\circ} \mathrm{C}$, to determine the leaf blade expressed as sward percentage and LBM. Sward height $(\mathrm{cm})$ was measured on the same measurement dates.

In order to maintain the intended leaf blade mass, grazing was carried out using Charolais and crossbred Nellore $\times$ Charolais heifers, approximately 14 months of age with $230 \mathrm{~kg}$ average initial body weight. The grazing method used was continuous with variable stocking rate (Mott \& Lucas, 1952), with three testers per paddock and a variable number of additional heifers. The stocking rate was adjusted weekly, through visual assessments of herbage mass, and every fifteen days after double sampling technical evaluation. Experimental heifers had free access to water and mineral salt.

The herbage bulk density ( $\mathrm{kg} / \mathrm{ha} / \mathrm{cm} \mathrm{DM})$ was evaluated (Stobbs, 1975b) on three areas of the sward per experimental unit that were representative of the intended leaf blade masses on 12/31/2001, 1/25, 2/21 and 4/4/2002, considering individual numbers to describe the sward condition. Leaf blade and stem bulk density were evaluated using the same methodology. Sampling was carried out using $1 \mathrm{~m}^{2}$ squares. In each square the herbage was cut considering four strata: 
ground level to $15 \mathrm{~cm} ; 15$ to $30 \mathrm{~cm}$; 30 to $45 \mathrm{~cm}$; and above $45 \mathrm{~cm}$ from the ground. The evaluations were made from the top to bottom of the sward. All forage mass within the same strata were cut and weighed and, in the same experimental unit, samples were taken by strata which were separated into stems and leaf sheath, leaf blade and dead material components. The components were then dried in a forced air oven and weighed to calculate the bulk density of the components.

Ingestive behaviour was assessed by visual observation (Jamieson \& Hodgson, 1979), at 10 minutes intervals in three continuous 48 -hour periods (1/18-1/19; 2/15-2/16 and 3/15-3/16/2002). Three testers were observed in each paddock and their activities were classified as grazing, idling or ruminating. Bite rates (bite/minute) were evaluated in the same heifers throughout the grazing activity time by measuring the time taken by the animals to take twenty bites (Hodgson, 1982). Grazing frequency was calculated based on the numbers of animals grazing in each hour of evaluation, considering $100 \%$ when all animals present on each paddock were grazing.

A randomized complete design following a repeated measure arrangement was used (grazing periods), with two treatments (leaf blade mass) and three replications (paddocks). The total experimental period was subdivided into three periods, from $12 / 31 / 2001$ to $1 / 25 / 2002$ (1-26 days); from $1 / 26 / 2002$ to $2 / 23 / 2002$ (27-54 days) and from $2 / 24 / 2002$ to 4/4/2002 (55-94 days). The following mathematical model was used to analyze pasture parameters:

$Y i j k=\mu+L B M i+P j+R k(L B M) i+(L B M * P) i j+\sum i j k$

where Yijk = dependent variables; $\mu=$ mean of all observations; LBMi = effect of ith blade leaf mass; $\mathrm{Pj}=$ effect of jth period; Rk (LBM)i = effect of kth replicate within the ith leaf blade mass (error A); LBM*Pij = effect of ith leaf blade mass $\times$ jth period interaction; $\Sigma$ ijk $=$ experimental error (error B).

For animal behaviour related variables, the animals were also inserted in the model. Data were submitted to analyses of variance at the level of $5 \%$ significance by the
F test and when differences were detected, means were compared by the Student $t$ test (PDIFF). The analyses were carried out using SAS Mixed PROC (SAS, 1996).

\section{Results and Discussion}

There was leaf blade mass $(\mathrm{LBM}) \times$ days of use interaction for sward height and herbage mass $(\mathrm{P}<0.05)$. Management with 1,000 kg/ha leaf blade DM, throughout the experimental period, resulted on the highest sward height and, within the 55-94 days of experimental period also the greatest herbage mass (Table 1 ). These interactions showed that the use of herbage mass or sward height values as a criteria in order to keep the intended LBM value might not be adequate because of changes in the leaf/stem ratio during the Pearl Millet cycle, which changed from 1.6 (1-26 days) to 0.6 (55-94 days). Increase in the sward stem contribution as growing season progressed was also reported in tropical grasses by Sbrissia \& Da Silva (2001).

Herbage offer was similar in both leaf blade masses, with values of 12.4 and $14.5 \mathrm{~kg}$ of $\mathrm{DM} / 100 \mathrm{~kg} \mathrm{LW}$, respectively, for leaf blade masses of 600 and $1,000 \mathrm{~kg} / \mathrm{ha} \mathrm{DM}$. According to Hodgson (1982) the highest levels of intake and animal performance are related to forage offer values around twice or three times the herbivore's daily DM nominal intake value. From available data, it appears that forage offer in both leaf blade masses probably did not limit DM intake by grazing animals.

In tropical forage grasses, in order to understand the forage grazing and intake process, in addition to the sward height, the mass and forage offer, plant component distribution along the sward vertical structure should also be considered (Carvalho et al., 2001; Roman et al., 2008). For leaf blade bulk density there was strata $\times$ leaf blade mass interaction (Table 2) and the 15 to $30 \mathrm{~cm}$ stratum showed the highest leaf blade bulk density $(\mathrm{P}<0.05)$ in both leaf blade masses evaluated.

The lowest leaf blade bulk density $(\mathrm{P}<0.05)$ occurred in both the upper and lower strata, regardless of the leaf blade

Table 1 - Sward height and herbage mass of Pearl Millet pasture managed at two leaf blade masses

\begin{tabular}{lccc}
\hline Leaf blade mass (kg/ha DM) & \multicolumn{2}{c}{ Days after starting pasture utilization } \\
\cline { 2 - 4 } & $1-26$ & Sward height (cm) & $55-94$ \\
\hline & & $27.5 \mathrm{c}$ & $26.9 \mathrm{c}$ \\
1,000 & $37.5 \mathrm{~b}$ & $40.0 \mathrm{ab}$ & $47.7 \mathrm{a}$ \\
600 & $49.2 \mathrm{a}$ & Herbage mass (kg/ha DM) & $1,574.1 \mathrm{bc}$ \\
1,000 & & $1,419.9 \mathrm{c}$ & $3,359.9 \mathrm{a}$ \\
\hline
\end{tabular}

Means with different lower case letters represent treatment $\times$ grazing cycle interaction by the PDIFF test $(\mathrm{P}<0.05)$ 
Table 2 - Vertical strata $\times$ leaf blade mass interaction on leaf blade mass bulk density in Pearl Millet pasture managed at two leaf blade masses

\begin{tabular}{lcc}
\hline Strata $(\mathrm{cm})$ & \multicolumn{2}{c}{ Leaf blade mass } \\
\cline { 2 - 3 } & 600 & 1,000 \\
\hline & Leaf blade bulk density $(\mathrm{kg} / \mathrm{ha} / \mathrm{cm}$ of $\mathrm{DM})$ \\
+45 & - & $19.6 \mathrm{bc}$ \\
$30-45$ & $18.4 \mathrm{bc}$ & $26.3 \mathrm{ab}$ \\
$15-30$ & $22.9 \mathrm{ab}$ & $29.1 \mathrm{a}$ \\
$0-15$ & $18.8 \mathrm{bc}$ & $13.4 \mathrm{c}$ \\
\hline \multicolumn{2}{l}{ Means with different lower case letters represent the strata $\times$ treatment interaction }
\end{tabular}
by the PDIFF test $(\mathrm{P}<0.05)$.

mass evaluated. However, the lowest leaf blade density in the upper stratum (Table 2) occurred due to the dispersion of emergent leaf blades and to the animal's selective intake, since grazing is done by stratum and the upper stratum is preferred because it is where the best quality forage is found (Carvalho et al., 2001). The lowest leaf blade density, found at the lower stratum of the canopy, from 0 to $15 \mathrm{~cm}$, is the result of stem and dead material accumulation that normally occurs due to low luminosity and to the growth habit of the plant, which were also reported by Palhano et al. (2007b) and Roman et al. (2008).

Considering the leaf blade density, there was interaction between the vertical strata and evaluation dates of the pasture canopy structure in Pearl Millet managed at two leaf blade masses (Table 3).

The highest leaf blade density was observed in the $15-30 \mathrm{~cm}$ stratum on 12/30/2001, and the lowest densities were observed in the lower stratum (0-15) and at evaluations made on 3/21 and 4/4/2002 (Table 3). The average leaf blade mass observed in the lower stratum was $241.2 \mathrm{~kg} / \mathrm{ha} \mathrm{DM}$, as a consequence of the arrangement of the leaves along the sward, which are distributed mainly in the upper stratum because they are the main photosynthetic apparatus of the plants, responsible for incident light absorption (Taiz \& Zeiger, 2004). The highest leaf blade bulk density observed on $12 / 30 / 2001$ reflected the initial pasture structure that grew without the influence of herbivores, and changed to a structure in which grazing was present. Selective grazing reduced leaf blade bulk density in all strata, in the following evaluations. Due to the short period of time planned for Pearl Millet pasture use, the specified targets for leaf blade mass were accomplished in the first evaluation period, and the structure was ready at the end of 21 days. Grazing caused the removal of most of the leaf blade available in the first evaluation, because animals prioritize grazing this component (Hodgson, 1990), which modified component distribution along the canopy. These densities, however, were all inferior to the ones observed in the $15 \mathrm{~cm}$ to $30 \mathrm{~cm}$ stratum on $12 / 30 / 2001$, because plants not affected by grazing can have a larger number of leaves and the size of these leaves can be bigger in comparison to plants which are grazed frequently, and this exemplifies plant tolerance to herbivory mechanisms (Briske, 1991).

In the evaluation on $4 / 4 / 2002$, the leaf blade bulk density was similar in all the strata, because of the considerable increase in the canopy with the advance of the Pearl Millet cycle and subsequent increase in dead material and stem participation, especially in the lower stratum (Roman et al., 2008). These changes reduced the leaf blade contribution (Table 2) due to flowering apex differentiation, when leaf blade/stem rates naturally decrease with stem elongation and decrease in leaf appearance and elongation rates (Skinner \& Nelson, 1995).

Regarding the stem bulk density, there was interaction among vertical strata, leaf blade mass and evaluation dates (Table 4$)$. The highest stem density $(\mathrm{P}<0.05)$ was observed from 0 to $30 \mathrm{~cm}$ at the end of experimental period on pasture managed with $1,000 \mathrm{~kg} / \mathrm{ha}$ DM leaf blade mass (Table 4) and the lowest, in the stratum from 15 to $30 \mathrm{~cm}$ in the first period of use on pasture managed with $600 \mathrm{~kg} / \mathrm{ha}$ DM leaf blade mass.

Pearl Millet management with $600 \mathrm{~kg} / \mathrm{ha}$ DM leaf blade mass promoted lower stem bulk density in the $0-45 \mathrm{~cm}$ stratum, throughout the whole experimental period (Table 4). When sward was managed with $1,000 \mathrm{~kg} / \mathrm{ha}$ DM leaf blade mass, an increase in the stem bulk density above 15 to $30 \mathrm{~cm}$ (Table 4) was observed from March onwards. The increase in the stem bulk density makes it more difficult for animals

Table 3 - Strata $\times$ dates of evaluation interaction on leaf blade bulk density in the vertical strata in Pearl Millet (average of two leaf blade masses)

\begin{tabular}{lccccc}
\hline Strata $(\mathrm{cm})$ & \multicolumn{5}{c}{ Date of evaluation } \\
\cline { 2 - 6 } & $12 / 30 / 2001$ & $1 / 25 / 2002$ & $2 / 21 / 2002$ & $3 / 21 / 2002$ & $4 / 4 / 2002$ \\
\hline & & Leaf blade bulk density $(\mathrm{kg} / \mathrm{ha} / \mathrm{cm}$ of DM) & - \\
+45 & - & $19.6 \mathrm{bcd}$ & - & $17.5 \mathrm{bcd}$ & $12.3 \mathrm{~d}$ \\
$30-45$ & $34.1 \mathrm{ab}$ & $23.8 \mathrm{bc}$ & $22.6 \mathrm{bc}$ & $19.1 \mathrm{bcd}$ & $11.5 \mathrm{~d}$ \\
$15-30$ & $44.1 \mathrm{a}$ & $26.6 \mathrm{bc}$ & $28.5 \mathrm{~b}$ & $12.1 \mathrm{~d}$ & $16.5 \mathrm{~cd}$ \\
$0-15$ & $19.2 \mathrm{bcd}$ & $15.3 \mathrm{~cd}$ & $17.4 \mathrm{bcd}$ & \\
\hline
\end{tabular}

Means with different lower case letters represent the interaction between strata $\times$ dates of evaluation by the PDIFF test $(\mathrm{P}<0.05)$. 
to reach leaf blades, which can modify bite depth and forage intake (Da Silva, 2006).

Maintaining $600 \mathrm{~kg} / \mathrm{ha}$ DM leaf blade mass proved to be more efficient to control stem growth than management with a greater leaf blade mass. However, pasture management with lesser leaf blade mass could have forced the heifers to ingest more stem components while heifers on pastures with a bigger leaf blade mass had a better opportunity to select leaves instead of stems. Progress in Pearl Millet development and increase in of the stem elongation rate as a consequence of flowering (Skinner \& Nelson, 1995) were also important as causes of higher stem bulk density on pasture managed with $1,000 \mathrm{~kg} / \mathrm{ha} \mathrm{DM}$, which was observed from $3 / 21 / 2002$ onwards.

Heifers kept on pastures with $1,000 \mathrm{~kg} / \mathrm{ha}$ DM leaf blade mass showed the lowest $(\mathrm{P}<0.05)$ bite rate (Table 5). The leaf blade masses evaluated resulted in distinct sward structures, which were verified by the canopy heights, forage mass (Table 1), leaf blade bulk density (Table 2 and 3 ) and stems (Table 4). These differences caused different intake behaviours, since lower bite rates, such as those observed in animals kept on pastures managed with $1,000 \mathrm{~kg} / \mathrm{ha} \mathrm{DM}$ LBM are associated with heavier bites which require a longer time of apprehension and manipulation for each bite (Da Silva \& Sarmento, 2005; Carvalho et al., 2007).

There was no difference $(\mathrm{P}>0.05)$ in grazing, rumination and idling time for heifers grazing Pearl Millet managed at the two evaluated leaf blade masses. Time dedicated daily to grazing was 490.2 and 483.7 minutes/day for leaf blade masses of 600 and 1,000 kg/ha DM, respectively. Changes in the ingestive behaviour, with higher bite rates at $600 \mathrm{~kg} / \mathrm{ha}$ DM LBM (Table 5) were probably enough to compensate lower bite mass so there was no need to modify grazing time in the different sward structures (Tables 2, 3 and 4).

Daily grazing, rumination and idling time and heifer bite rate changed during Pearl Millet pasture use (Table 6), which was also reported by Carvalho et al. (2007). Changes in sward structure over time, according to these authors, also need to be considered in order to understand variables that rule the grazing process and forage intake. Horizontal (distribution of patches) and vertical (strata) structure variations could interfere and cause variation in animal grazing behaviour, even in single species pastures.

Interactions between leaf blade mass and days of pasture use for grazing, rumination and idling time and bite rate $(\mathrm{P}>0.05)$ were not observed. The longer time dedicated to grazing $(\mathrm{P}<0.05)$ in the first period (1-26 days) of pasture use is a reflex of the initial sward structure, as discussed, since the canopy was more open, with longer leaves, forcing the animals to apprehend them one by one, which results in more time needed to take the bites (Carvalho et al., 2001; Palhano et al., 2007). The lower bite rate observed during this period (Table 6) indicated that the animals needed more time to apprehend and manipulate the forage due to the leaf blade distribution in the vertical sward structure (Carvalho et al., 2001; Da Silva \& Sarmento, 2005). The rumination time, longer in the 1-26 days period, was also affected by forage manipulation and apprehension activities, which are the factors that cause the major impact on the bite rate and mass and are basically determined by the grazed plant architecture (Carvalho, 1997), because, the longer the rumination time is, the larger will the bites taken by the grazing animal (Stobbs, 1975a).

Time dedicated to social interactions (idling) is inversely related to the grazing animal's need to keep up forage intake rates. Longer grazing and rumination times reduced time dedicated to idling $(\mathrm{P}<0.05)$, because they were excluding activities.

The average grazing frequency was 32.7 and $30.2 \%$, respectively, for leaf blade mass of 600 and $1,000 \mathrm{~kg} / \mathrm{ha} \mathrm{DM}$ (Figure 2).

Three important grazing times peaks are usually observed: the first in the early morning, the second one at sunset and the third, generally shorter, at night (Bremm et al., 2005). The collected data (Figure 2) confirmed the observation that the first meal of the day of a grazing animal normally begins

Table 4 - Strata $\times$ sward structure $\times$ evaluation date interaction on stem bulk density in the vertical strata of Pearl Millet pasture managed at two leaf blade masses

\begin{tabular}{|c|c|c|c|c|c|c|c|c|c|c|}
\hline \multirow[t]{4}{*}{ Strata $(\mathrm{cm})$} & \multicolumn{10}{|c|}{ Leaf blade mass (kg/ha of DM) } \\
\hline & \multirow{2}{*}{\multicolumn{4}{|c|}{600}} & \multirow{2}{*}{\multicolumn{3}{|c|}{ Date of evaluation }} & \multirow{2}{*}{\multicolumn{3}{|c|}{1,000}} \\
\hline & & & & & & & & & & \\
\hline & $12 / 30 / 2001$ & $1 / 25 / 2002$ & $2 / 21 / 2002$ & $3 / 21 / 2002$ & $4 / 4 / 2002$ & $12 / 30 / 2001$ & $1 / 25 / 2002$ & $2 / 21 / 2002$ & $3 / 21 / 2002$ & $4 / 4 / 2002$ \\
\hline+45 & - & - & - & - & - & - & - & - & - & - \\
\hline $30-45$ & - & 10.4ghij & - & - & - & 3.3ijk & 7.2ghij & 9.2ghij & 24.8cdefghi & $49,7 \mathrm{bc}$ \\
\hline $15-30$ & $0.66 \mathrm{j}$ & 33.4cde & 3.5ijk & 8.4ghij & 7.4ghij & 2.5hjk & 16.4efghij & 16.8efghij & 22.6cdefghi & $66,3 a$ \\
\hline $0-15$ & 13.0fghi & $41.8 \mathrm{bc}$ & 11.8ghij & 23.7cdefghi & $31.8 \mathrm{cdef}$ & 15.3efghij & 26.5cdefg & 17.6defghij & $36.0 \mathrm{~cd}$ & $57,4 \mathrm{ab}$ \\
\hline
\end{tabular}

Different lower case letters represent the treatment $\times$ evaluation date $\times$ strata interaction by the PDIFF test $(\mathrm{P}<0.05)$ 
Table 5 - Pearl Millet leaf blade mass and bite rate of grazing beef heifers

\begin{tabular}{|c|c|c|c|c|}
\hline \multirow[t]{2}{*}{ Variables } & \multicolumn{3}{|c|}{ Target leaf blade mass (kg/ha DM) } & \multirow[t]{2}{*}{ CV (\%) } \\
\hline & & 600 & 1,000 & \\
\hline $\begin{array}{l}\text { Actual leaf blade } \\
\text { (kg/ha of } \mathrm{DM})\end{array}$ & nass & $641.7 b$ & $1,023.8 \mathrm{a}$ & 26.0 \\
\hline Bite rate (bite/mi & nute) & $41.1 \mathrm{a}$ & $37.0 \mathrm{~b}$ & 15.7 \\
\hline
\end{tabular}

Means followed by the same lower case letters on the line are not different $(\mathrm{P}>0.05)$ by the PDIFF test.

minutes after sunrise, around 6 a.m (Carvalho et al.. 2005) after the animals have been through a long period of grazing inactivity during the night, when the rumination process prevails as activity and the rumen empties what had been previously ingested. At both leaf blade masses, a higher grazing frequency occurred between 6 am and 7 pm (26\% between 6 a.m. and 12 p.m and $32 \%$ between 12 p.m and 6 p.m) and decreased progressively with the beginning of the night, restarting between 11 p.m. and 1 a.m. (16\% of the total grazing time), in a similar way to that observed by Bremm et al. (2005) in Italian ryegrass pasture. The highest temperature was $28.3^{\circ} \mathrm{C}$ during the experimental period (Figure 1 ) and it seems that this did not affect the grazing activity of the animals on pasture, because decrease in the grazing frequency during the hottest hours of the day, from 10 a.m. to 4 p.m., was not observed.

Table 6 - Grazing, rumination and idling daily times, in minutes/day and beef heifers bite rate (bites/minute) during the period of use of Pearl Millet pasture (average of two leaf blade masses)

\begin{tabular}{|c|c|c|c|c|}
\hline \multirow[t]{2}{*}{ Variable } & \multicolumn{3}{|c|}{ Days after the start of pasture use } & \multirow[t]{2}{*}{ CV (\%) } \\
\hline & $1-26$ & $27-54$ & $55-94$ & \\
\hline Grazing & $549 a$ & $456 b$ & $457 b$ & 18.5 \\
\hline Rumination & $547 a$ & $479 b$ & $480 \mathrm{~b}$ & 10.5 \\
\hline Idling & 282b & $442 \mathrm{a}$ & $443 a$ & 16.5 \\
\hline Bite rate & $24.9 b$ & $46.5 a$ & $46.7 \mathrm{a}$ & 15.7 \\
\hline
\end{tabular}

Means followed by the same lower case letters on the line are not different $(\mathrm{P}>0.05)$ by the PDIFF test.

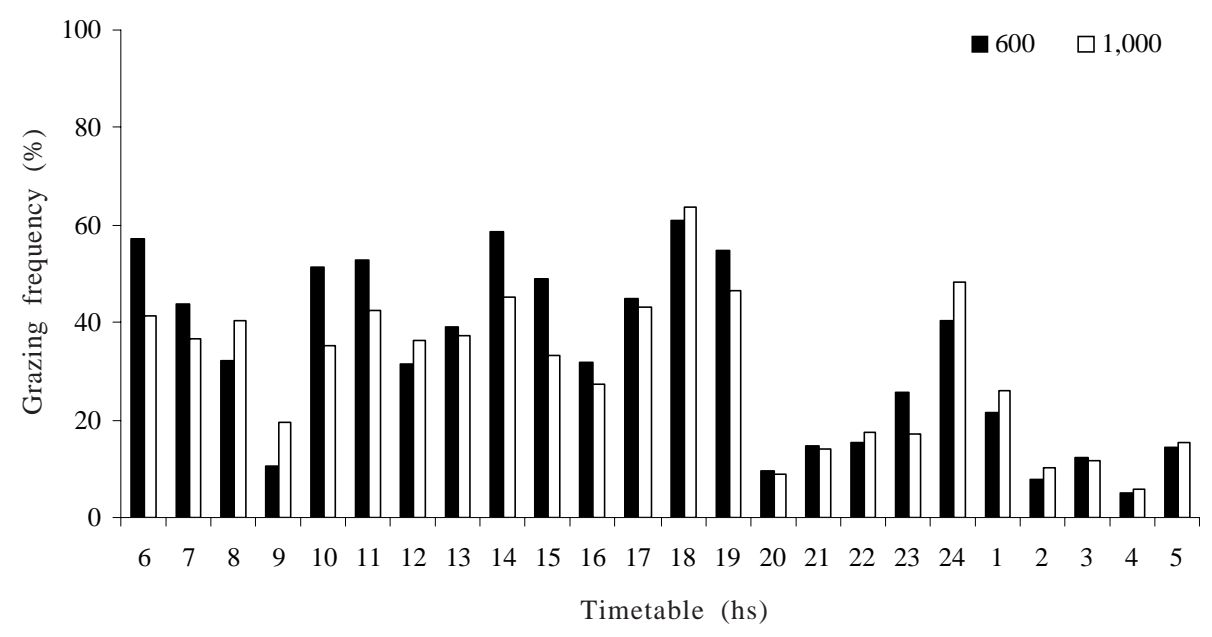

Figure 2 - Grazing frequency (\% of grazing heifers) on Pearl Millet managed at two leaf blade masses.

\section{Conclusions}

The instantaneous structure of Pearl Millet sward, represented by leaf blade mass, influenced grazing animals ' bite rate. Bite rates were higher in the lower sward leaf blade masses evaluated. Beef heifer grazing, rumination and idling time did not change when the value of the leaf blade mass varied from 600 to $1,000 \mathrm{~kg} / \mathrm{ha} \mathrm{DM}$. Bite rate modifications are enough to establish the same level of dry matter intake for grazing animals, even with different sward structure, promoted by differences in sward height, leaf blade mass and vertical distribution of the sward components. The structural variations over time (pasture cycle) modify animal grazing and rumination time and affect bite rates. 


\section{Acknowledgements}

The authors would like to thank the Universidade Federal de Santa Maria and the Conselho Nacional de Desenvolvimento Científico e Tecnológico (CNPq) for overall support. The authors thank PhD José Henrique Souza da Silva (UFSM) and Msc Luciana Pötter (UFSM) and Carolina Bremm (UFRGS) for help with the statistical analysis. They also thank the students of Setor de Forragicultura of the Universidade Federal de Santa Maria - UFSM.

\section{Literature Cited}

BREMM, C.; ROCHA, M.G.; RESTLE, J. et al. Efeito de níveis de suplementação sobre o comportamento ingestivo de bezerras em pastagem de aveia (Avena strigosa Schreb.) e azevém (Lolium multiflorum Lam.). Revista Brasileira de Zootecnia, v.34, n.2, p.387-397, 2005.

BRISKE, D.D. Developmental morphology and physiology of grasses. In: HEITSCHMIDT, R.K.; STUTH, J.W. (Eds.) Grazing management. Portland: Timber, 1991. p.85-108.

CARVALHO, P.C. Relações entre a estrutura da pastagem e o comportamento ingestivo de ruminantes em pastejo. In: SIMPÓSIO SOBRE AVALIAÇÃO DE PASTAGENS COM ANIMAIS, 1., 1997, Maringá. Anais... Maringá: Universidade Estadual de Maringá, 1997. p.25-52.

CARVALHO, P.C.F.; GENRO, T.C.M.; GONÇALVES, E.N. et al. A estrutura do pasto como conceito de manejo: reflexos sobre o consumo e a produtividade. In: REIS, R.A.; SIQUEIRA, G.R.; BERTIPAGLIA, L.M.A. et al. (Orgs.) Volumosos na produção de ruminantes, 2005, Jaboticabal. Anais... Jaboticabal: Fundação de Apoio a Pesquisa, Ensino e Extensão, 2005. p.107-124.

CARVALHO, P.C.F.; KOZLOSKI, G.V.; RIBEIRO FILHO, H.M.N. et al. Avanços metodológicos na determinação do consumo de ruminantes em pastejo. Revista Brasileira de Zootecnia, v.36, p.151-170, 2007 (supl. especial).

CARVALHO, P.C.F.; RIBEIRO FILHO, H.M.N.; POLI, C.H.E.C. et al. Importância da estrutura da pastagem na ingestão de dietas pelo animal em pastejo. In: MATTOS, W.R.S. (Ed.) REUNIÃO ANUAL DA SOCIEDADE BRASILEIRA DE ZOOTECNIA. A produção animal na visão dos brasileiros, 38., 2001, Piracicaba. Anais... Piracicaba: Fundação de Estudos Agrários Luiz de Queiroz, 2001. p.853-871.

DA SILVA, S.C. Comportamento animal em pastejo. In: SIMPÓSIO SOBRE MANEJO DA PASTAGEM, 23., 2006, Piracicaba. Anais... Piracicaba: Fundação de Estudos Agrários Luiz de Queiroz, 2006. p.221-248.

DA SILVA, S.C.; SARMENTO, D.O.L. Consumo de forragem sob condições de pastejo. In: REIS, R.A.; SIQUEIRA, G.R.; BERTIPAGLIA, L.M.A. et al. (Orgs.). Volumosos na produção de ruminantes, 2005, Jaboticabal. Anais... Jaboticabal: Fundação de Estudos Agrários Luiz de Queiroz, 2005. p.107-124.

EMPRESA BRASILEIRA DE PESQUISA AGROPECUÁRIA EMBRAPA. Centro Nacional de Pesquisa de Solos. Sistema brasileiro de classificação de solos. Brasília: EMBRAPA. 1999. 412p.

HERINGER. I.; CARVALHO, P.C.F. Ajuste da carga animal em experimentos de pastejo: uma nova proposta. Ciência Rural, v.32, n.4, p.675-679, 2002.
HODGSON, J. Grazing management: science into practice. England: Longman Scientific \& Technical, 1990. 203p.

HODGSON, J. Influence of sward characteristics on diet selection and herbage intake by the grazing animal. In: HACKER, J.B. (Ed.)Nutritional limits to animal production from pasture. Wallingford: CAB International, 1982. p.153-166.

JAMIESON, W.S.; HODGSON, J. The effect of daily herbage allowance and sward characteristics upon the ingestive behavior of calves under strip-grazing management. Grass and Forage Science, v.34, p.261-271. 1979.

LEMAIRE, G.; CHAPMANN, D. Tissue flows in grazed plants communities. In: HODGSON, J.; ILliUS, A.W. (Eds.) The ecology and management of grazing systems. Wallingford: CAB International, 1996. p.3-36.

MARASCHIN, G.E. Relembrando o passado, entendendo o presente e planejando o futuro: uma herança em forrageiras e um legado em pastagens. In: REUNIÃO ANUAL DA SOCIEDADE BRASILEIRA DE ZOOTECNIA, 2000, Viçosa, MG. Anais... Viçosa, MG: Sociedade Brasileira de Zootecnia, 2000. p.113-180.

MOTT, G.O.; LUCAS, H.L. The design, conduct, and interpretation of grazing trials in cultivated and improved pastures. In: INTERNATIONAL GRASSLAND CONGRESS, 6., 1952, Pennsylvania. Proceedings... Pennsylvania: State College Press. 1952. p.1380-1385.

PALHANO, A.L.; CARVALHO, P.C.F.; DITTRICH, J.R. et al. Estrutura da pastagem e padrões de desfolhação em capimmombaça em diferentes alturas do dossel forrageiro. Revista Brasileira de Zootecnia, v.34, n.6, p.1860-1870, 2007a.

PALHANO, A.L.; CARVALHO, P.C.F.; DITTRICH, J.R. et al. Características do processo de ingestão de forragem por novilhas holandesas em pastagem de capim-mombaça. Revista Brasileira de Zootecnia, v.36, n.4, p.1014-1021, 2007b (supl.).

REIS, R.A.; DA SILVA, S.C. Consumo de forragens. In: BERCHIELLI, T.T.; PIRES, A.V.; OLIVEIRA, S.G. (Eds.) Nutrição de ruminantes. Jaboticabal: Fundação de Apoio a Pesquisa, Ensino e Extensão, 2006. p.79-109.

ROMAN, J.; ROCHA, M.G.; GENRO, T.C.M. et al. Características produtivas e estruturais do milheto e sua relação com o ganho de peso de bezerras sob suplementação alimentar. Revista Brasileira de Zootecnia, v.37, n.2, p.205-211, 2008.

SBRISSIA, A.F.; DA SILVA, S.C. O Ecossistema de pastagens e a produção animal. In: MATTOS, W.R.S. (Ed.) A produção animal na visão dos brasileiros. Piracicaba: Sociedade Brasileira de Zootecnia, 2001. p.731-753.

SKINNER, R.H.; NELSON, C.J. Elongation of the grass leaf and its relationship to the phyllochron. Crop Science, v.35, n.1, p.4-10, 1995.

STATISTICAL ANALYSIS SYSTEM - SAS. Statistical analysis system user's guide. Version 6.08. Cary: SAS Institute, 1996. 1014p.

STOBBS, T.H. Factors limiting the nutritional value of grazed tropical pastures for beef and milk productions. Tropical Grasslands, v.9, p.141-149, 1975a.

STOBBS, T.H. The effect of plant structure on the intake of tropical pastures. III. Influence of fertilizer nitrogen on the bite harvested by jersey cows grazing Setaria anceps cv. Kazungula sward. Australian Journal of Agricultural Research, v.26, p.997-1007, 1975b.

t'MANNETJE, L. Measuring biomass of grassland vegetation. In: t'MANNETJE, L.; JONES, R.M. (Eds.) Field and laboratory methods for grassland and animal production research. Wallingford: CABI Publishing/CAB International, 2000. p.151-177. 